\title{
Mengelola Komitmen Dosen: Analisis Peran Modal Psikologis dan Leaders Coaching
}

\author{
Dewiana Novitasari ${ }^{1 *}$ \\ Masduki Asbari \\ Lala Hucadinota Ainul Amri ${ }^{3}$ \\ Dhaniel Hutagalung 4 \\ ${ }^{1}$ Sekolah Tinggi Ilmu Ekonomi Insan Pembangunan, Tangerang, Indonesia \\ *Email: dhewiediosa@yahoo.co.id \\ ${ }^{2}$ STMIK Insan Pembangunan, Tangerang, Indonesia \\ Email: kangmasduki.ssi@gmail.com \\ ${ }^{3}$ Politeknik Negeri Media Kreatif, Jakarta, Indonesia \\ Email: lalahuca@polimedia.ac.id \\ ${ }^{4}$ Sekolah Tinggi Ilmu Ekonomi Insan Pembangunan, Tangerang, Indonesia \\ Email: dhanielhutagalung@gmail.com
}

\begin{abstract}
Abstrak
Komitmen dosen merupakan kebutuhan krusial dan fundamental untuk menjaga keberlangsungan proses pendidikan dan pembelajaran di perguruan tinggi. Karena sejatinya, perguruan tinggi merupakan institusi knowledge creator dan produsen sumber daya manusia unggul yang menjadi tumpuan masa depan generasi. Unuk itu, menghadirkan komitmen dosen dalam dalam praksis berdasarkan usaha dan konsep teoritis yang proven menjadi penting dan genting. Penelitian ini bertujuan untuk menguji pengaruh leaders coaching terhadap komitmen tim dosen, serta untuk menyelidiki efek mediasi modal psikologis pada populasi dosen dari salah satu perguruan tinggi swasta di Banten. Penelitian ini mengadopsi metode simple random sampling dengan 61 sampel dosen. Hasil penelitian ini menunjukkan bahwa leaders coaching memiliki pengaruh yang signifikan terhadap modal psikologis dan komitmen tim dosen. Hasil penelitian juga menunjukkan bahwa hubungan antara leaders coaching dan komitmen tim secara signifikan dimediasi oleh modal psikologis. Penelitian ini dapat membuka jalan untuk meningkatkan kesiapan dosen dalam menghadapi era education 4.0.
\end{abstract}

Kata kunci: Komitmen tim, leaders coaching, modal psikologis.

\section{PENDAHULUAN}

Coaching merupakan metodologi yang efektif untuk mengembangkan kepemimpinan, meningkatkan kesejahteraan, dan memfasilitasi pencapaian tujuan organisasi. Penelitian awal yang menggunakan studi kasus subjek tunggal kualitatif atau metodologi berbasis wawancara melaporkan bahwa coaching bisa efektif dalam membantu para eksekutif di organisasi komersial, mengembangkan gaya kepemimpinan yang lebih positif dan konstruktif (misalnya, Diedrich (1996)). Penelitian lain telah melaporkan bahwa coaching bisa meningkatkan gaya kepemimpinan dan meningkatkan fleksibilitas manajerial dan kemampuan pemecahan masalah (misalnya, Jones et al. (2006)). Dalam studi terkontrol secara acak, Grant et al. (2009) menemukan itu coaching yang dilakukan oleh coach profesional meningkatkan ketahanan, kesejahteraan di tempat kerja, dan tujuan pencapaian untuk para eksekutif dan manajer senior di sebuah badan perawatan kesehatan masyarakat Australia. Di A.S. Pengaturan tentara, menggunakan desain dalam subjek, Bowles et al. (2007) menemukan coaching itu meningkatkan kualitas hidup manajer perekrutan distrik. Dalam pengaturan Angkatan Darat A.S. yang serupa, tetapi menggunakan desain antara subjek, Bowles et al. (2007) menemukan bahwa coaching sangat efektif untuk manajemen menengah (dibandingkan dengan manajer eksekutif) dalam hal pengembangan kepemimpinan dan pencapaian tujuan yang ditetapkan sendiri. Selain penelitian di tempat kerja atau organisasi, sejumlah studi telah menemukan bahwa coaching dalam konteks non-kerja dapat meningkatkan kesejahteraan dan ketahanan, memfasilitasi tujuan pencapaian, dan mengurangi kecemasan, stres, atau depresi (misalnya, Bowles \& Picano (2006)). Jadi, secara keseluruhan ada bukti yang muncul bahwa coaching dapat menjadi metodologi perubahan yang efektif untuk berbagai kalangan populasi. Berbeda dengan Bowles et al. (2007), Grant (2013) menyebutkan bahwa belum meyakinkan bahwa coaching menghasilkan perubahan yang berkelanjutan dan permanen, dan untuk itu diperlukan penelitian yang lebih meluas, mendalam dan bersifat longitudinal. Untuk 
itulah, penelitian ini dilakukan, lebih khusus pada dunia pendidikan, yang sejatinya menjadi sumber penciptaan pengetahuan, sekaligus produsen sumber daya manusia yang unggul dan kompeten.

\section{Coaching dalam Praktik Pendidikan}

Banyak literatur yang melaporkan tentang coaching dalam pengaturan pendidikan, terutama yang terkait dengan tujuan meningkatkan pembelajaran mahasiswa atau membimbing mahasiswa untuk mengatasi keaksaraan tertentu atau kesulitan belajar (misalnya, Merriman \& Codding (2008)). Ada literatur yang muncul tentang dosen yang menerima coaching sendiri (untuk tinjauan berguna tentang perbedaan pendekatan untuk melatih dosen dalam pengaturan pendidikan. Pendekatan ini mencakup coaching teknis atau instruksional yang dirancang untuk meningkatkan keterampilan instruksional dosen dan coaching praktik reflektif, yang merupakan "proses di mana dosen mengeksplorasi pemikiran di balik praktek mereka"(Garmston et al., 1993). Secara umum penggunaan istilah tersebut coaching dalam pengaturan pendidikan mengacu pada cakupan aplikasi yang sangat luas, dan sangat sedikit di antaranya kutipan mengacu pada kepemimpinan atau coaching eksekutif yang dilakukan oleh pembina kepemimpinan profesional atau konsultan. Coaching untuk pengembangan profesional atau kepemimpinan dalam pengaturan pendidikan sebagian besar dilakukan dengan menggunakan coaching sebaya, dan pendekatan ini telah digunakan dengan dosen pemula dan pendidik yang lebih berpengalaman (Garmston et al., 1993). Namun, seperti dalam organisasi komersial, beberapa manajemen senior dalam pengaturan pendidikan juga terlibat dalam beberapa coaching pengembangan bawahan (Asbari, 2019; Jumiran et al., 2020; Nuryanti et al., 2020; Sudiyono et al., 2020; Suroso et al., 2021; Yuwono et al., 2020).

Penelitian peer-review pada topik coaching profesional untuk pendidik memang masih terbatas. Namun, pencarian sepintas di internet menunjukkan bahwa para praktisi menawarkan pengembangan professional coaching untuk sektor pendidikan memiliki nilai yang substansial. Dosen di perguruan tinggi dapat memiliki pengaruh yang besar terhadap mahasiswanya. Seorang dosen, sejatinya adalah perwujudan kepemimpinan di ruang-ruang kelas pembelajaran. Mereka tidak hanya memberikan arahan, bimbingan, dan umpan balik kepada mahasiswa mereka (Agistiawati et al., 2020; Hutagalung et al., 2020; Lestari et al., 2020; Novitasari, Asbari, et al., 2020; Novitasari, Yuwono, et al., 2020), tapi mereka juga bertindak sebagai teladan seperti yang sering mereka lakukan di depan mahasiswa mereka di perguruan tinggi, bahkan hingga dalam kehidupan umum di luar perguruan tinggi. Jika seorang manajer dari sebuah perusahaan dipanggil manajer hanya tatkala di lingkungan perusahaan, tapi tidak dengan profesi dosen. Profesi dosen ternyata terus melekat melampaui batas-batas ruang kelas di perguruan tinggi. Pengertian dosen sebagai pemimpin yang digunakan dalam beberapa penelitian mengacu pada konsep kepemimpinan diri (Manz \& Sims Jr, 1980) dan kepemimpinan transformasional (Bass \& Avolio, 1994). Kepemimpinan diri mengacu pada kapasitas individu untuk mengontrol perilaku mereka sendiri, mempengaruhi dan memimpin diri melalui penggunaan strategi perilaku dan kognitif khusus yang dirancang untuk meningkatkan efektivitas pribadi. Tidak hanya melakukan kepemimpinan diri dengan baik untuk diri sendiri, tetapi individu yang menunjukkan perilaku kepemimpinan diri yang baik dapat menjadi teladan penting dalam membina keterampilan kepemimpinan diri serupa pada orang lain (Manz \& Sims Jr, 1980). Jelas, ini keterampilan kepemimpinan yang penting bagi dosen untuk dikembangkan.

Beberapa tantangan utama yang dihadapi dosen perguruan tinggi adalah termasuk stres, kurangnya sumber daya, peningkatan pengawasan dan evaluasi dari para pemangku kepentingan utama, berurusan dengan birokrasi yang rumit, menangani secara konstruktif populasi mahasiswa yang beragam, dan kebutuhan untuk menampilkan hal yang positif saat berada di bawah tekanan (MacKenzie \& Marnik, 2008). Selain itu, sebuah tantangan kunci yang dihadapi sektor perguruan tinggi adalah retensi staf pengajar (Quartz, 2003). Tentu saja, tantangan ini dapat bervariasi tergantung pada jenis perguruan tingginya, Antara perguruan tinggi negeri dan perguruan tinggi swasta. Sejatinya, hal ini adalah tantangan perkembangan yang serupa dengan dengan tantangan yang dihadapi oleh organisasi komersial, yakni bagaimana proses coaching efektif bisa dilakukan sejak dari lini eksekutif.

Meskipun kerangka teoritis yang digunakan dalam coaching sangat bervariasi, mulai dari perilaku dan kognitif, hingga psikodinamik dan berfokus pada solusi (Kunst et al., 2018), sesungguhnya yang mendasari semua praktik coaching adalah seperangkat prinsip umum. Hal ini termasuk pengertian tentang kolaborasi dan akuntabilitas, peningkatan kesadaran, tanggung jawab, 
komitmen, perencanaan tindakan, dan tindakan. Artinya, terlepas dari orientasi teoretisnya, hubungan coaching adalah satu di mana coach dan orang yang dibina (coachee) membentuk aliansi kerja kolaboratif, yang ditetapkan bersama tentang tujuannya, dan merancang langkah-langkah tindakan khusus yang berorientasi pada pencapaian tujuan tersebut (Hunt \& Weintraub, 2016). Tanggung jawab coachee adalah pelaksanaan langkah-langkah tersebut, sedangkan peran coach adalah untuk menjaga orang yang dibina (coachee) tetap fokus pada tujuan, membantu memantau dan mengevaluasi kemajuan dari waktu ke waktu serta menyediakan waktu untuk brainstorming dan refleksi diri.

Dengan demikian, coaching untuk kepemimpinan atau pengembangan profesional mungkin efektif melalui setidaknya empat mekanisme kognitif dan perilaku yang mendasari (Franks, 2018). Pertama, memiliki sifat suportif dan hubungan rahasia, di mana untuk membahas masalah pribadi dan profesional dapat mengurangi kecemasan dan stres dan meningkatkan keterampilan kepemimpinan diri. Kedua, menerima umpan balik tentang perilaku kepemimpinan seseorang yang ada dapat meningkatkan kesadaran akan area untuk pengembangan. Umpan balik semacam itu dalam konteks hubungan yang suportif dan rahasia dapat menyediakan platform penting untuk perubahan yang disengaja dan pengembangan perilaku kepemimpinan yang konstruktif dan transformasional. Ketiga, menetapkan tujuan yang sesuai dengan diri sendiri dan dihargai secara pribadi yang ditujukan pada masalah yang dibahas dalam proses umpan balik dan kemudian dengan sengaja bekerja untuk mencapainya dapat memfasilitasi pengembangan perilaku baru, serta membangun efikasi diri dan meningkatkan kesejahteraan. Keempat, terlibat secara sistematis dalam hal tersebut aktivitas selama periode waktu tertentu dan didukung dalam mengatasi setiap kemunduran dapat membangun ketahanan dan mengembangkan keterampilan kepemimpinan diri. Hasil dari, proses coaching mungkin mengalami peningkatan kepercayaan diri, kepuasan kerja, dan juga kesejahteraan sehingga menjadi lebih siap untuk menghadapi perubahan dan stres di tempat kerja (Sutardi et al., 2020a).

Coaching telah menjadi strategi pengembangan sumber daya manusia jangka panjang (Hackman \& Wageman, 2005) dan telah menarik banyak perhatian dari banyak organisasi selama bertahun-tahun. Manajemen perguruan tinggi dan sarjana telah melihat coaching yang efektif sebagai salah satu praktik terbaik untuk mencapai manajemen, kepemimpinan, dan pembelajaran yang sukses dalam sebuah organisasi (Ellinger et al., 2003). Manajemen perguruan tinggi atau supervisor yang bertindak sebagai Pembina di tempat kerja, bekerja sama dengan dosen untuk mengidentifikasi penyebab kesenjangan kinerja dan memberikan umpan balik kepada dosen. Telah disarankan bahwa coaching yang efektif dapat meningkatkan moral dan kepercayaan diri dosen, meningkatkan pengetahuan dan kemampuan dosen, dan mempromosikan sikap kerja dan perilaku dosen yang positif, sehingga berkontribusi pada kinerja organisasi secara keseluruhan.

Menurut organizational support theory (OST) dan perceived organization support (POS) yang diusulkan oleh Eisenberger et al. (1986), ketika dosen merasa bahwa organisasi menghargai kontribusi mereka, memenuhi kebutuhan mereka, dan peduli dengan kesejahteraan mereka- menjadi (level POS yang lebih tinggi), norma timbal balik (Bernarto et al., 2020) membangkitkan rasa kewajiban mereka untuk membantu organisasi mencapai tujuannya (Eisenberger et al., 1986). Penelitian sebelumnya telah menunjukkan bahwa POS memiliki dampak positif terhadap hasil kerja pegawai seperti kepuasan kerja, kinerja kerja, komitmen organisasi, dan intensi turnover (Arshadi, 2011) karena hal tersebut menimbulkan kewajiban pada pegawai untuk membalas kembali kebaikan organisasi. Mengikuti logika ini dan membangun OST, penelitian ini bertujuan untuk menyelidiki hubungan antara leaders coaching, modal psikologis, kinerja, dan komitmen tim. Hackman \& Wageman (2005) menunjukkan bahwa coach yang efektif dapat memotivasi anggota tim untuk menyelesaikan tugas dan menghasilkan pembelajaran aktif, sehingga meningkatkan kinerja tugas tim. (Ellinger et al., 2003) menekankan bahwa Pembina dapat menampilkan perilaku leaders coaching yang efektif dengan menetapkan tujuan, berkomunikasi secara efektif, memotivasi dosen, mencatat kinerja dan memberikan umpan balik, serta mengembangkan dosen. Menggambar pada perspektif OST, penelitian ini mengasumsikan bahwa manajemen perguruan tinggi atau supervisor yang menunjukkan perilaku leaders coaching yang efektif akan meningkatkan tingkat efikasi diri, harapan, optimisme, dan ketahanan modal psikologis dosen. Pada gilirannya, pola pikir positif ini dapat meningkatkan kewajiban dosen untuk menunjukkan 
sikap dan perilaku kerja yang positif yang bermanfaat bagi organisasi. Karena tidak ada penelitian yang mengeksplorasi hubungan antara leaders coaching, modal psikologis, dan komitmen tim, penelitian ini bermaksud untuk mempertimbangkan leaders coaching sebagai variabel anteseden sambil memperlakukan modal psikologis sebagai variabel mediasi dan melihat komitmen tim sebagai perilaku dan hasil sikap masing-masing dosen.

Selain itu, penelitian ini juga menggunakan Conservation of Resources Theory (COR) Hobfoll (1989) sebagai landasan teoritis untuk menggambarkan hubungan antara modal psikologis dan hasil kerja yaitu, temuan penelitian ini dapat berfungsi sebagai referensi berharga bagi manajemen perguruan tinggi dengan meningkatkan kesadaran tentang bagaimana perilaku coaching yang efektif dapat memotivasi modal psikologis positif tim dosen, yang mengarah ke tim dosen yang berkinerja tinggi dan berdedikasi tinggi, yang berkontribusi pada pertumbuhan organisasi perguruan tinggi yang berkelanjutan dan membangun peradaban bangsa (Asbari \& Novitasari, 2021; Sutardi et al., 2020b). Temuan dari penelitian ini akan menjadi contributor pada the body of knowledge pada model coaching di dunia pendidikan, sekaligus menguatkan konsep dari teori yang telah disebutkan di atas.

\section{KAJIAN PUSTAKA DAN PENGEMBANGAN HIPOTESIS Leaders Coaching}

Istilah coach pada awalnya digunakan dalam olahraga pada tahun 1880-an. Coach atau coach dipandang sebagai instruktur yang menginstruksikan individu atlit (misalnya, tenis, golf, dan ski) dan tim pemain (misalnya, bola basket, sepak bola, dan dayung) tentang cara meningkatkan performance mereka. Coach telah memainkan peran utama yang penting bagi individu dan tim dalam olahraga paling terorganisir selama seabad yang lalu (Evered \& Selman, 1989). Dalam pengaturan kerja, inti dari peran seorang coach adalah untuk memberdayakan dosen dengan mempromosikan pembelajaran mandiri, pertumbuhan pribadi, dan peningkatan kinerja (Bresser \& Wilson, 2010). Dikombinasikan dengan coaching dan kepemimpinan, leaders coaching didefinisikan sebagai aktivitas yang memungkinkan manajemen perguruan tinggi untuk mempromosikan pembelajaran, mendorong penemuan diri terhadap apa yang ingin dicapai bawahan, dan membimbing mereka untuk meningkatkan kinerja (Whitmore, 2010).

Dalam hal keterampilan leaders coaching, literatur konseptual dan praktisi biasanya menggambarkan keterampilan mendengarkan, analitis, wawancara, pertanyaan, dan observasi sebagai hal yang penting bagi seorang coach. Namun, kemampuan untuk menerjemahkan keterampilan coaching menjadi hasil nyata terkait pekerjaan yang berguna juga penting untuk leaders coaching. Penelitian sebelumnya tentang leaders coaching menunjukkan bahwa perilaku leaders coaching termasuk memberi dan menerima umpan balik kinerja, mengkomunikasikan dan menetapkan harapan yang jelas, menciptakan dan mempromosikan lingkungan belajar yang mendukung, menyediakan sumber daya, mentransfer kepemilikan kepada dosen, dan memperluas perspektif dosen (Longenecker \& Neubert, 2005). Ellinger et al. (2003) mengidentifikasi setidaknya ada delapan perilaku leaders coaching. Penelitian sebelumnya mengungkapkan bahwa leaders coaching dapat menghasilkan kinerja yang diinginkan (Arshadi, 2011). Studi ini akan mengkaji kinerja dosen dan komitmen tim dosen sebagai hasil perilaku dan sikap dari leaders coaching di lingkungan kerja perguruan tinggi.

\section{Modal Psikologis}

Modal psikologis didefinisikan sebagai "keadaan perkembangan psikologis positif individu" (Luthans \& Youssef-Morgan, 2017a). Hal ini mencakup empat komponen: kemanjuran diri, harapan, optimisme, dan ketahanan. Di dalam ranah perguruan tinggi, Efikasi diri berarti bahwa dosen memiliki kepercayaan diri untuk melakukan upaya yang diperlukan agar berhasil menyelesaikan tugas belajar dan mengajar yang menantang. Harapan berarti dosen bekerja keras untuk mencapai tujuan mereka. Untuk menjadi sukses, mereka dapat memilih kembali metode pencapaian tugas bila diperlukan. Optimisme berarti bahwa dosen menghubungkan peristiwa positif dengan individu dengan cara yang bertahan lama dan meluas dan menghubungkan peristiwa negatif dengan faktor kontekstual eksternal. Dengan kata lain, mereka memberikan atribusi positif untuk kesuksesan saat ini dan masa depan. Ketahanan mengacu pada kemampuan dosen untuk menanggapi dan menyelesaikan masalah mereka sendiri ketika mereka menghadapi kesulitan atau kesulitan (Luthans \& Youssef-Morgan, 2017a). 
Sebuah studi empiris oleh Luthans \& Youssef-Morgan (2017a) menemukan bahwa empat komponen modal psikologis memiliki proses kognitif dan motivasi yang berpotensi interaktif. Luthans \& Youssef-Morgan (2017a) menunjukkan bahwa kombinasi keempat ini lebih efektif daripada satu komponen individu karena lebih dapat memprediksi kinerja dosen dan kepuasan dosen. Orang dengan modal psikologis positif tingkat tinggi, akan lebih percaya diri dalam menerima tugas yang menantang dan memiliki keyakinan kuat pada kesuksesan, motivasi untuk bekerja keras saat menghadapi kesulitan, dan kemampuan untuk bangkit kembali dari bawah dan memulai kembali saat dibutuhkan.

\section{Komitmen Tim}

Komitmen organisasi dapat didefinisikan sebagai keterikatan psikologis pegawai dengan organisasi (Meyer et al., 1997). Artinya, di dalam organisasi perguruan tinggi, komitmen organisasi adalah sejauh mana seorang dosen terlibat dalam organisasi perguruan tingginya dan kekuatan identifikasinya dengan perguruan tinggi tempat dirinya berkarya. Seorang dosen dengan komitmen organisasi yang tinggi memiliki keyakinan yang kuat dalam organisasi, menerima nilai-nilai dan misi organisasi, bersedia melakukan upaya yang cukup besar untuk keuntungan organisasi, dan memiliki keinginan yang kuat untuk mempertahankan keanggotaan dalam organisasi (Mowday et al., 1982). Berkomitmen pada tim dalam organisasi dapat berarti bahwa keterikatan psikologis individu lebih kuat kepada tim daripada ke organisasi (Pearce \& Herbik, 2004), hal yang sama juga menjadi hasil penelitian Asbari et al. (2021); Novitasari et al. (2020); Purwanto et al. (2021). Penelitian sebelumnya menunjukkan bahwa komitmen tim dapat didefinisikan dengan cara yang sama seperti komitmen organisasi; yaitu, ditandai dengan penerimaan nilai dan tujuan tim, kemauan untuk berjuang untuk tim, dan keinginan untuk mempertahankan keanggotaan dalam tim (Schlechter \& Strauss, 2008).

\section{Pengaruh Leaders Coaching terhadap Komitmen Tim}

Menurut OST Eisenberger et al. (1986), dukungan manajemen merupakan sumber daya penting yang dapat digunakan dosen untuk meningkatkan kinerjanya. Leaders coaching dapat dilihat sebagai bentuk dukungan sosial yang diberikan oleh manajemen perguruan tinggi dalam informasi dan umpan balik terkait pekerjaannya. Manajemen perguruan tinggi menggunakan proses umpan balik untuk mengungkapkan rasa terima kasih mereka kepada para dosen atas upaya dan pencapaian mereka. Ketika dosen merasa dihargai oleh perguruan tinggi, maka memungkinkan mereka untuk mencurahkan lebih banyak energi dan waktu untuk meningkatkan kinerja mereka dan dengan demikian menguntungkan perguruan tinggi (Eisenberger et al., 1986).

Dalam literatur leaders coaching yang masih ada, penelitian yang melimpah telah mengeksplorasi hubungan yang disebutkan di atas antara leaders coaching dan kinerja. Namun, hubungan antara leaders coaching dan komitmen tim belum diselidiki. Untuk mengisi kesenjangan tersebut, penelitian ini menggunakan tim sebagai acuan untuk komitmen organisasi dan mengikuti penelitian komitmen organisasi oleh Mowday et al. (1982), yang memprediksi hubungan positif antara leaders coaching dan komitmen tim. Artinya, perilaku leaders coaching yang efektif (misalnya, memberikan umpan balik kinerja, mengkomunikasikan dan menetapkan harapan yang jelas, menciptakan dan mempromosikan lingkungan belajar yang mendukung, dan menyediakan sumber daya) kemungkinan besar untuk menginspirasi komitmen dosen terhadap tim, unit, atau departemen mereka. Dengan demikian, hipotesis berikut dikembangkan.

H1: Leaders coaching berpengaruh positifterhadap komitmen tim.

\section{Pengaruh Leaders Coaching terhadap Modal Psikologis}

Manajemen perguruan tinggi yang berperan sebagai coach efektif adalah manajemen perguruan tinggi yang mengarahkan anggota tim dalam lingkungan kerja dengan baik. Seseorang yang sedang dilatih disebut orang yang dibina (coachee). Menurut Hunt \& Weintraub (2016), coaching yang efektif lebih kuat dan berguna daripada hanya memberikan umpan balik kepada dosen dengan masalah kinerja belajar dan mengajar. Hunt \& Weintraub (2016) menyatakan bahwa manajemen perguruan tinggi yang berperan sebagai managerial coach mempromosikan refleksi dan pembelajaran; mereka mendorong dosen untuk merasa memiliki masalah dan mengembangkan serta secara aktif berpartisipasi dalam pekerjaan mereka. Hunt \& Weintraub (2016) memiliki pandangan serupa, menyatakan bahwa coaching adalah praktik yang membantu memandu dosen, kelompok, dan organisasi untuk mendapatkan keahlian, kinerja, dan 
kemampuan baru untuk mempromosikan peningkatan, efisiensi, dan pertumbuhan pribadi mereka. Mengingat definisi coaching di lingkungan kerja, penelitian ini mengasumsikan bahwa leaders coaching dapat meningkatkan aspek efikasi diri, harapan, optimisme, dan ketahanan modal psikologis dosen. Oleh karena itu, hipotesis berikut dikembangkan.

H2: Leaders coaching berpengaruh positif terhadap modal psikologis.

\section{Pengaruh Modal Psikologis terhadap Komitmen Tim}

Di tempat kerja, teori COR dari Hobfoll (1989) menyatakan bahwa dosen akan melestarikan, melindungi, dan memelihara sumber daya yang mereka hargai ketika (1) ada ancaman kehilangan sumber daya; (2) ada kehilangan sumber daya yang sebenarnya; dan (3) ketidakmampuan untuk menginvestasikan sumber daya. Ketika dosen gagal menerima atau merasakan balasan atas sumber daya yang telah mereka berikan, mereka akan merasakan ketidaknyamanan psikologis. Sumber daya ini meliputi: sumber daya objek, kondisi, karakteristik pribadi, dan energi. Modal psikologis dapat dikatakan sebagai sumber daya individu. Dalam konteks perguruan tinggi, dosen dengan modal psikologis positif biasanya mengharapkan hal-hal baik terjadi di tempat kerja (optimisme), percaya bahwa mereka dapat melakukan pekerjaan dengan baik (self-efficacy dan harapan), dan tidak mudah mengalami kemunduran/kekecewaan (ketahanan).

Jadi, mdal psikologis adalah elemen psikologis yang positif. Semakin tinggi modal psikologis seseorang, maka semakin mudah individu tersebut menerapkan persepsi dan pemahaman positif terhadap hal-hal di sekitarnya. Ketika dihadapkan pada kesulitan dan kemunduran di tempat kerja, individu dengan modal psikologis yang kuat cenderung akan menghadapinya dengan sikap dan perilaku yang positif. Hal ini terbukti dalam penelitian terkini tentang modal psikologis. Misalnya, sebuah studi meta-analisis yang dilakukan oleh Avey et al. (2011) menunjukkan bahwa modal psikologis yang terdiri dari harapan, optimisme, efikasi, dan ketahanan berhubungan signifikan dengan komitmen organisasi, perilaku warga negara, dan kinerja. Yu et al. (2019) meneliti hubungan antara anteseden dan konsekuensi modal psikologis menggunakan sampel 208 pengusaha dari Filipina. Hasil studi mereka mengungkapkan bahwa modal psikologis memiliki pengaruh yang signifikan dan positif terhadap kepuasan kerja, kinerja, dan perilaku kewarganegaraan organisasi. Yildiz(2017) melakukan studi empiris tentang pengaruh modal psikologis dan kepribadian terhadap komitmen organisasi pada 217 pegawai kerah putih dan biru. Hasil mereka menunjukkan bahwa modal psikologis berpengaruh positif terhadap komitmen afektif, kontinuitas, dan normatif organisasi. Mengingat penelitian sebelumnya ini (Avey et al., 2011; Yildiz, 2017), penelitian ini mengasumsikan bahwa dalam konteks tim, unit, atau departemen, modal psikologis berhubungan positif dengan kinerja dan komitmen tim. Dengan demikian, hipotesis berikut dikembangkan.

H3: Modal psikologis berpengaruh positifterhadap komitmen tim.

\section{Efek Mediasi Modal Psikologis}

Berkenaan dengan mekanisme yang menghubungkan coaching dengan hasil kerja pegawai, beberapa peneliti sebelumnya telah memberikan berbagai bukti empiris. Kim et al. (2013) meneliti pengaruh perilaku leaders coaching pada reaksi pegawai terkait pekerjaan di antara 482 pegawai di organisasi publik Korea. Kim et al. (2013) memandang perilaku leaders coaching sebagai variabel independen, menganggap kejelasan peran pegawai dan kepuasan dengan hasil kerja sebagai variabel mediator, dan menganggap karir dan komitmen organisasi dan kinerja pegawai sebagai variabel dependen. Mereka menemukan efek mediasi yang signifikan dalam hipotesis kejelasan peran model yang dimediasi pada kinerja; kepuasan dengan pekerjaan yang dimediasi karir dan komitmen organisasi. Selain itu, Raza et al. (2018) menggunakan teknik analisis model persamaan struktural (SEM) untuk menguji pengaruh leaders coaching terhadap organizational citizenship behavior (OCB) di antara 361 pegawai. Temuan mereka mengungkapkan bahwa modal psikologis yang berkembang baik di tempat kerja secara signifikan memediasi hubungan antara leaders coaching dan OCB. Studi tersebut di atas telah mengkonfirmasi adanya variabel mediator dalam hubungan antara coaching dan hasil kerja. Diantaranya, penelitian ini akan mengkaji modal psikologis sebagai mediator. Sebagaimana dikemukakan dalam penelitian sebelumnya, modal psikologis memegang peranan penting dalam meningkatkan sikap dan perilaku kerja positif dosen, dan telah diverifikasi secara luas sebagai konsep penting dari teori psikologi positif (Avey et al., 2011; Story et al., 2013). Mengikuti 
alur pemikiran ini, penelitian ini menganggap modal psikologis sebagai mediator potensial dan mengasumsikan bahwa leaders coaching secara tidak langsung mempengaruhi kinerja kerja dan komitmen tim dosen melalui modal psikologis. Berdasarkan OST, studi saat ini memprediksi bahwa manajemen perguruan tinggi yang menunjukkan perilaku coaching yang efektif dapat meningkatkan keadaan psikologis positif para dosen (yaitu, efikasi diri, harapan, optimisme, dan ketahanan), yang pada gilirannya meningkatkan komitmen tim dosen. Oleh karena itu, hipotesis berikut dikembangkan.

H4: Modal psikologis secara signifikan memediasi hubungan antara leaders coaching dan komitmen tim.

Model konseptual yang diusulkan berdasarkan hipotesis ditunjukkan pada Gambar 1 .

\section{Kerangka Konsep Penelitian}

Menurut Sekaran \& Bougie (2003) kerangka teoritis merupakan fondasi di mana seluruh proyek penelitian didasarkan. Dari kerangka teoritis bisa disusun hipotesis yang dapat diuji untuk mengetahui apakah teori yang dirumuskan valid atau tidak. Lalu kemudian selanjutnya akan dapat diukur dengan analisis statistik yang tepat. Mengacu pada teori dan penelitian terdahulu terdapat hubungan antara variable-variabel berikut: leaders coaching, modal psikologis, dan komitment tim dosen. Untuk itu, penulis membangun model penelitian sebagai mana disebut pada Gambar 1 berikut:

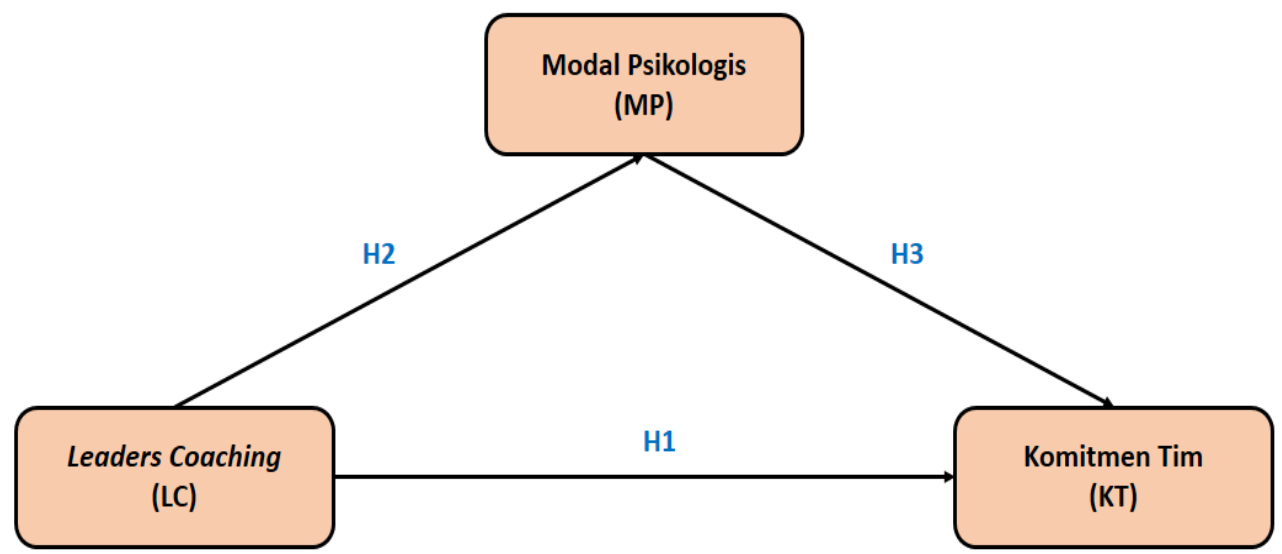

Gambar 1. Model Penelitian

\section{METODE}

\section{Definisi Operasional Variabel dan Indikator}

Metode yang digunakan dalam penelitian ini adalah metode kuantitatif. Dilakukan pengumpulan data dengan mengedarkan angket kepada seluruh dosen perempuan pada lima perdosenan tinggi swasta di Banten. Instrumen yang digunakan untuk mengukur Leaders coaching diadaptasi dari Ye et al. (2016) dengan menggunakan delapan item (LC1-LC6). Leaders coaching didefinisikan sebagai manajemen perguruan tinggi yang memberdayakan dosen dengan mempromosikan pembelajaran mandiri, pertumbuhan pribadi, dan peningkatan kinerja (Bresser \& Wilson, 2010). Instrumen yang digunakan untuk mengukur modal psikologis diadaptasi dari Slåtten et al. (2020) dengan menggunakan 4 items (MP1-MP4). Modal psikologis didefinisikan sebagai keadaan perkembangan psikologis positif seseorang yang ditandai dengan efikasi diri, optimisme, harapan dan ketahanan (Luthans \& Youssef-Morgan, 2017b). Instrumen komitmen tim dosen diadaptasi dari Bishop \& Scott (2000) dengan menggunakan 8 items (KT1-KT8). Komitmen Tim didasarkan pada definisi istilah Bishop \& Scott (2000), yaitu bahwa anggota tim tidak hanya menerima tujuan dan nilai tim, tetapi juga bekerja keras untuk tim dan berharap untuk terus menjadi bagian dari tim.

Model penelitian dapat dilihat sebagaimana pada Gambar 1. Angket didesain tertutup kecuali untuk pertanyaan/pernyataan mengenai identitas responden yang berupa angket semi terbuka. Tiap item pertanyaan/pernyataan tertutup diberikan lima opsi jawaban, yaitu: sangat setuju (SS) skor 5, setuju (S) skor 4, netral (N) skor 3, tidak setuju (TS) skor 2, dan sangat tidak setuju (STS) skor 1. Metode untuk mengolah data adalah dengan PLS dan menggunakan software SmartPLS versi 3.0 sebagai toolnya. 


\section{Populasi dan Sampel}

Populasi dalam penelitian ini adalah dosen dari salah satu perguruan tinggi swasta di Banten yang jumlahnya 76 orang. Kuesioner disebarkan dengan teknik simple random sampling. Hasil kuesioner yang kembali sebanyak valid adalah 61 sampel. Jadi jumlah sampel adalah $80.3 \%$ dari jumlah populasi.

Tabel 1. Daftar Item Penelitian

\begin{tabular}{|c|c|c|}
\hline Notasi & Item & Referensi \\
\hline \multicolumn{2}{|c|}{ Leaders Coaching (LC) } & Ye et al. (2016) \\
\hline $\mathrm{LC} 1$ & $\begin{array}{l}\text { Atasan saya mempertanyakan bawahannya untuk memahami mengapa } \\
\text { tujuan mereka penting bagi masa depan profesi mereka sendiri. }\end{array}$ & \\
\hline $\mathrm{LC} 2$ & $\begin{array}{l}\text { Atasan saya membantu bawahan memikirkan siapa, kapan dan bagaimana } \\
\text { menyelesaikan tugas. }\end{array}$ & \\
\hline LC3 & $\begin{array}{l}\text { Atasan saya menghabiskan banyak waktu untuk meninjau kemajuan } \\
\text { bawahan untuk menentukan apakah penyesuaian diperlukan. }\end{array}$ & \\
\hline $\mathrm{LC} 4$ & $\begin{array}{l}\text { Atasan saya menghabiskan banyak waktu untuk membantu bawahan } \\
\text { meningkatkan kinerja mereka. }\end{array}$ & \\
\hline LC5 & Atasan saya berusaha keras untuk mengembangkan bawahan. & \\
\hline LC6 & $\begin{array}{l}\text { Atasan saya menghabiskan waktu mencari peluang untuk pengembangan } \\
\text { profesional bawahan. }\end{array}$ & \\
\hline \multicolumn{2}{|c|}{ Modal Psikologis (MP) } & Slåtten et al. (2020) \\
\hline MP1 & $\begin{array}{l}\text { Saya merasa yakin bahwa saya dapat menetapkan tujuan untuk diri saya } \\
\text { sendiri di area kerja saya. }\end{array}$ & \\
\hline MP2 & Saya optimis tentang masa depan saya di kampus ini. & \\
\hline MP3 & $\begin{array}{l}\text { Ketika dihadapkan pada tantangan dalam pekerjaan saya, saya dapat } \\
\text { menemukan solusi alternatif penyelesaiannya }\end{array}$ & \\
\hline MP4 & Saya dapat menemukan cara alternatif untuk mencapai tujuan saya & \\
\hline \multicolumn{2}{|c|}{ Komitmen Tim (KT) } & Bishop \& Scott (2000) \\
\hline KT1 & $\begin{array}{l}\text { Saya menceritakan tim dosen ini kepada teman-teman saya sebagai tim yang } \\
\text { hebat }\end{array}$ & \\
\hline KT2 & $\begin{array}{l}\text { Saya akan menerima hampir semua pekerjaan untuk tetap bekerja dengan } \\
\text { tim ini }\end{array}$ & \\
\hline KT3 & Saya menemukan bahwa nilai-nilai saya dan nilai-nilai tim sangat mirip & \\
\hline KT4 & Saya bangga memberi tahu orang lain bahwa saya adalah bagian dari tim ini & \\
\hline KT5 & $\begin{array}{l}\text { Tim ini benar-benar menginspirasi yang terbaik dalam diri saya dalam } \\
\text { mendukung kinerja saya }\end{array}$ & \\
\hline KT6 & $\begin{array}{l}\text { Saya sangat senang bahwa saya memilih tim ini untuk bekerja sama dengan } \\
\text { tim lain }\end{array}$ & \\
\hline KT7 & Saya sangat peduli dengan nasib tim ini & \\
\hline KT8 & $\begin{array}{l}\text { Bagi saya, tim ini adalah yang terbaik dari semua tim yang ada yang } \\
\text { mendukung pekerjaan saya }\end{array}$ & \\
\hline
\end{tabular}

\section{HASIL DAN PEMBAHASAN}

\section{Deskripsi Sampel}

Total ada 61 dosen yang berpartisipasi. Sebagaimana di sebutkan pada Tabel 2, mereka memiliki kelompok umur yang berbeda-beda, berkisar antara di bawah usia 29 tahun (25\%), 30-49 tahun $(57 \%)$, dan lebih dari usia 50 tahun (18\%). Masa kerja mereka juga beragam, 33\% di antaranya di bawah 5 tahun, 54\% sudah bekerja antara 5-10 tahun, dan 13\% sisanya telah bekerja lebih dari 10 tahun. Pendidikan tertinggi responden adalah mayoritas setingkat Sarjana S2 (75\%), kemudian S3 yakni $25 \%$. 
Table 2. Deskripsi Sampel

\begin{tabular}{llcc}
\hline Kriteria & & Jml. & \% \\
\hline Usia & $<29$ thn. & 15 & $25 \%$ \\
& $30-49$ thn. & 35 & $57 \%$ \\
Masa kerja sebagai dosen & $>50$ thn. & 11 & $18 \%$ \\
& $<5$ thn. & 20 & $33 \%$ \\
Ijazah tertinggi & $5-10$ thn. & 33 & $54 \%$ \\
& $>10$ thn. & 8 & $13 \%$ \\
& S3 & 15 & $25 \%$ \\
\hline
\end{tabular}

Sumber: Data Diolah (2021)

\section{Hasil Uji Validitas dan Reliabilitas Indikator Penelitian}

Tahap pengujian model pengukuran meliputi pengujian validitas konvergen, validitas diskriminan. Sementara untuk menguji reliabilitas konstruk digunakan nilai cronbach's alpha dan composite reliability. Hasil analisis PLS dapat digunakan untuk menguji hipotesis penelitian jika seluruh indikator dalam model PLS telah memenuhi syarat validitas konvergen, validitas deskriminan dan uji reliabilitas.

\section{Pengujian Validitas Konvergen}

Uji validitas konvergen dilakukan dengan melihat nilai loading factor masing-masing indikator terhadap konstruknya. Pada sebagian besar referensi, bobot faktor sebesar 0.7 atau lebih dianggap memiliki validasi yang cukup kuat untuk menjelaskan konstruk laten (Chin, 1998; Ghozali, 2014; Hair et al., 2010). Pada penelitian ini batas minimal besarnya loading factor yang diterima adalah 0.7 , dan dengan syarat nilai AVE setiap konstruk > 0.5 (Ghozali, 2014). Setelah melalui pengolahan SmartPLS 3.0, seluruh indikator telah memiliki nilai loading factor di atas 0.7 dan nilai AVE di atas 0.5. Model fit atau valid dari penelitian ini dapat dilihat pada Gambar 2. Jadi dengan demikian, validitas konvergen dari model penelitian ini sudah memenuhi syarat. Nilai loadings, cronbach's alpha, composite reliability dan AVE setiap konstruk selengkapnya dapat dilihat Tabel 2.

\section{Pengujian Validitas Deskriminan}

Discriminant validity dilakukan untuk memastikan bahwa setiap konsep dari masing-masing variabel laten berbeda dengan variabel laten lainnya. Model mempunyai discriminant validity yang baik jika nilai kuadrat AVE masing-masing konstruk eksogen (nilai pada diagonal) melebihi korelasi antara konstruk tersebut dengan konstruk lainnya (nilai di bawah diagonal) (Ghozali, 2014). Hasil pengujian discriminant validity adalah dengan menggunakan nilai kuadrat AVE, yakni dengan melihat FornellLarcker Criterion Value diperoleh sebagaimana ditunjukkan pada Tabel 3. Hasil uji validitas deskriminan pada tabel 3 di atas menunjukkan bahwa seluruh konstruk telah memiliki nilai akar kuadrat AVE di atas nilai korelasi dengan konstruk laten lainnya (melalui kriteria Fornell-Larcker). Demikian juga nilai cross-loading seluruh item dari suatu indikator lebih besar dari item indikator lainnya sebagaimana disebut pada Tabel 4, sehingga dapat disimpulkan bahwa model telah memenuhi validitas deskriminan (Fornell \& Larcker, 1981).

Selanjutnya dilakukan evaluasi collinearity untuk mengetahui ada tidaknya masalah collinearity pada model. Untuk menemukan collinearity tersebut, diperlukan statistik collinearity VIF dari setiap konstruk. Jika VIF lebih dari 5, maka model memiliki collinearity (Hair et al., 2014). Seperti yang ditunjukkan pada Tabel 4, semua skor VIF kurang dari 5, yakni hasil dari model struktural collinearity mengungkapkan nilai VIF di bawah 2. Hal ini menunjukkan bahwa model penelitian ini tidak ada masalah multikolinearitas.

\section{Pengujian Reliabilitas Konstruk}

Reliabilitas konstruk dapat dinilai dari nilai cronbach's alpha dan composite reliability dari masing-masing konstruk. Nilai composite reliability dan cronbach's alpha yang disarankan adalah lebih dari 0.7 (Ghozali, 2014). Hasil uji reliabilitas pada tabel 2 di atas menunjukkan bahwa seluruh konstruk telah memiliki nilai composite reliability dan cronbach's alpha lebih besar dari 0.7 (>0.7). Kesimpulannya, seluruh konstruk telah memenuhi reliabilitas yang dipersyaratkan. 


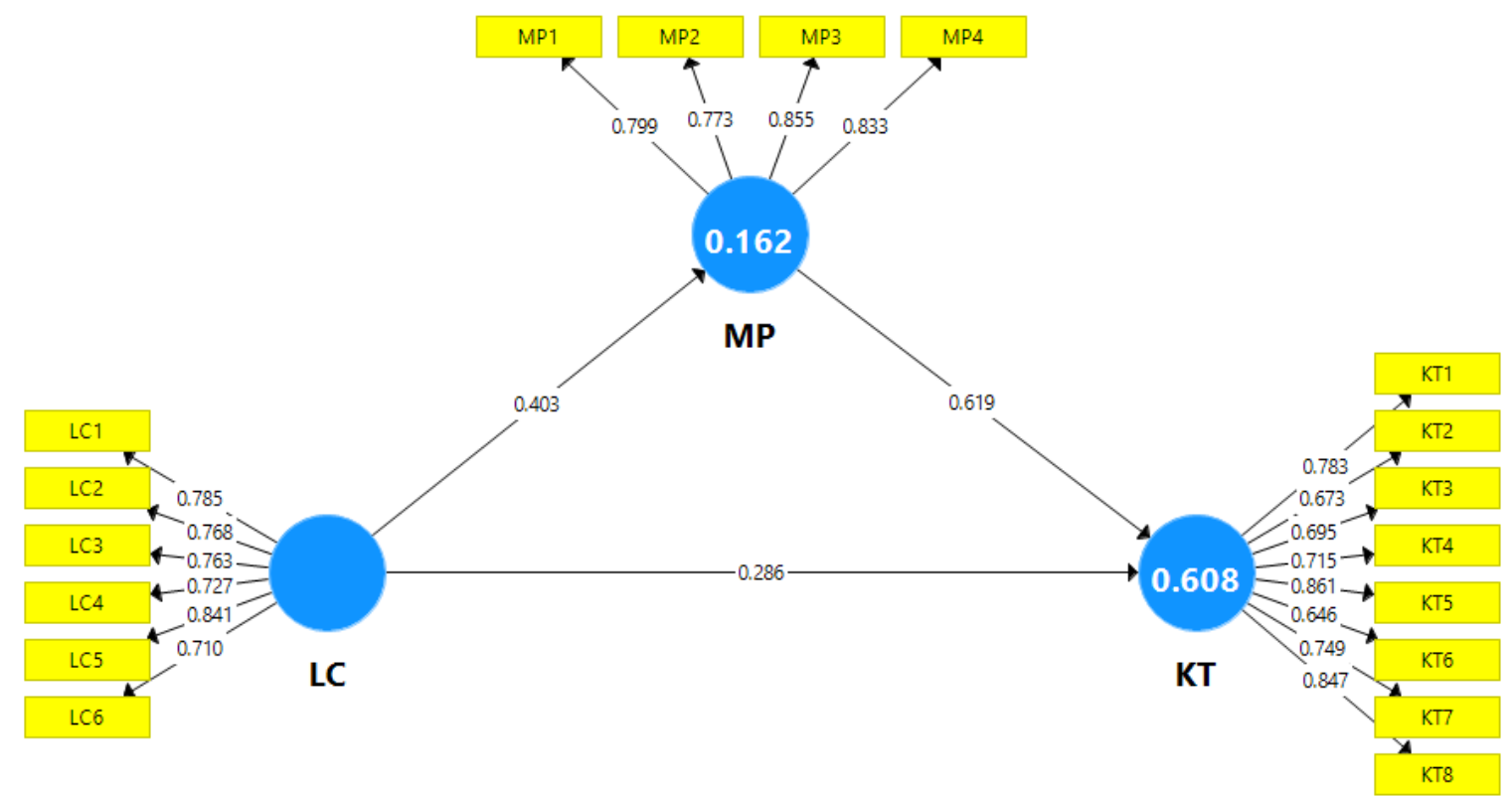

Gambar 2. Model Penelitian Valid

Sumber: Hasil Pengolahan SmartPLS 3.0 (2021)

Tabel 3. Items Loadings, Cronbach's Alpha, Composite Reliability, and Average Variance Extracted (AVE)

\begin{tabular}{|c|c|c|c|c|c|}
\hline Variables & Items & Loadings & $\begin{array}{l}\text { Cronbach's } \\
\text { Alpha }\end{array}$ & $\begin{array}{l}\text { Composite } \\
\text { Reliability }\end{array}$ & AVE \\
\hline \multirow{6}{*}{ Leaders coaching $(\mathrm{LC})$} & LC2 & 0.785 & \multirow[t]{6}{*}{0.859} & \multirow[t]{6}{*}{0.895} & \multirow[t]{6}{*}{0.588} \\
\hline & LC3 & 0.768 & & & \\
\hline & LC4 & 0.763 & & & \\
\hline & LC5 & 0.727 & & & \\
\hline & LC6 & 0.841 & & & \\
\hline & LC7 & 0.710 & & & \\
\hline \multirow{4}{*}{ Modal Psikologis (MP) } & MP1 & 0.799 & \multirow{4}{*}{0.832} & \multirow{4}{*}{0.888} & \multirow{4}{*}{0.665} \\
\hline & MP2 & 0.773 & & & \\
\hline & MP3 & 0.855 & & & \\
\hline & MP4 & 0.833 & & & \\
\hline \multirow[t]{8}{*}{ Komitmen Tim (KT) } & KT1 & 0.783 & \multirow[t]{8}{*}{0.887} & \multirow[t]{8}{*}{0.910} & \multirow[t]{8}{*}{0.562} \\
\hline & KT2 & 0.673 & & & \\
\hline & KT3 & 0.695 & & & \\
\hline & KT4 & 0.715 & & & \\
\hline & KT5 & 0.861 & & & \\
\hline & KT6 & 0.646 & & & \\
\hline & KT7 & 0.749 & & & \\
\hline & KT8 & 0.847 & & & \\
\hline
\end{tabular}

Sumber: Hasil Pengolahan SmartPLS 3.0 (2021)

Tabel 4. Discriminant Validity

\begin{tabular}{lccc}
\hline Variables & KT & LC & MP \\
\hline Komitmen Tim (KT) & $\mathbf{0 . 7 5 0}$ & & \\
Leaders coaching (LC) & 0.535 & $\mathbf{0 . 7 6 7}$ & \\
Modal Psikologis (MP) & 0.735 & 0.403 & $\mathbf{0 . 8 1 6}$ \\
\hline
\end{tabular}

Sumber: Hasil Pengolahan SmartPLS 3.0 (2021) 
Tabel 5. Collinearity (VIF)

\begin{tabular}{lcc}
\hline Variables & KT & LC \\
\hline Komitmen Tim (KT) & & MP \\
Leaders coaching (LC) & 1.194 & 1.000 \\
Modal Psikologis (MP) & 1.194 & \\
\hline
\end{tabular}

Sumber: Hasil Pengolahan SmartPLS 3.0 (2021)

Tabel 6. Nilai $R$ Square

\begin{tabular}{lcl}
\hline Variables & R Square & $\begin{array}{l}\text { R Square } \\
\text { Adjusted }\end{array}$ \\
\hline Komitmen Tim (KT) & 0.608 & 0.594 \\
Modal Psikologis (MP) & 0.162 & 0.148
\end{tabular}

Sumber: Hasil Pengolahan SmartPLS 3.0 (2021)

Tabel 7. Hypotheses Testing

\begin{tabular}{llccccc}
\hline Hypotheses & Relationship & Beta & SE & T Statistics & P-Values & Decision \\
\hline H1 & LC -> KT & 0.286 & 0.104 & 2.735 & 0.006 & Didukung \\
H2 & LC -> MP & 0.403 & 0.102 & 3.934 & 0.000 & Didukung \\
H3 & MP -> KT & 0.619 & 0.065 & 9.483 & 0.000 & Didukung \\
H4 & LC -> MP -> KT & 0.250 & 0.072 & 3.450 & 0.001 & Didukung \\
\hline
\end{tabular}

Sumber: Hasil Pengolahan SmartPLS 3.0 (2021)

\section{Pengujian Hipotesis}

Pengujian hipotesis dalam PLS disebut juga sebagai uji inner model. Uji ini meliputi uji signifikansi pengaruh langsung dan tidak langsung serta pengukuran besarnya pengaruh variabel eksogen terhadap variabel endogen. Untuk mengetahui pengaruh leaders coaching terhadap komitmen tim dosen melalui modal psikologis sebagai variable mediasi dibutuhkan uji pengaruh langsung dan tidak langsung. Uji pengaruh dilakukan dengan menggunakan uji t-statistik dalam model analisis partial least squared (PLS) dengan menggunakan bantuan software SmartPLS 3.0. Dengan teknik boothstrapping, diperoleh nilai $R$ Square dan nilai uji signifikansi sebagaimana Tabel 6 dan Tabel 7. Berdasarkan Tabel 6 di atas, nilai $R$ Square Modal Psikologis (MP) sebesar 0.162 yang berarti bahwa variable Modal Psikologis (MP) mampu dijelaskan oleh variabel leaders coaching (LC) sebesar 16.2\%, sedangkan sisanya sebesar $73.8 \%$ dijelaskan oleh variabel lain yang tidak dibahas dalam penelitian ini. Sementara itu, nilai $R$ Square Komitmen Tim (KT) sebesar 0.608 yang berarti bahwa variabel Komitmen Tim (KT) mampu dijelaskan oleh variabel leaders coaching (LC) dan variabel modal psikologis (MP) sebesar $60.8 \%$, sedangkan sisanya sebesar 39.2\% dijelaskan oleh variabel lain yang tidak dibahas dalam penelitian ini. Artinya bahwa substansi pengaruh dalam model hubungan pada model penelitian ini adalah terbilang kuat (Chin, 1998). Sedangkan Tabel 6 menampilkan $t$-statistics dan $p$-values yang menunjukkan pengaruh antar variable penelitian yang telah disebutkan.

\section{PEMBAHASAN}

Menurut teori dukungan organisasi/ organization support theory (OST) (Eisenberger et al., 1986), ketika dosen percaya bahwa organisasi menghargai kontribusi mereka dan peduli dengan kesejahteraan mereka, maka akan terjadi timbal balik (Gouldner, 1960), yakni membangkitkan rasa kewajiban dosen untuk memberi kembali organisasi dengan meningkatkan komitmen organisasi, antara lain. (Rhoades \& Eisenberger, 2002). Atas dasar OST, studi ini mengasumsikan bahwa ketika dosen merasa bahwa manajemen perguruan tinggi mereka menunjukkan perilaku coaching yang efektif, seperti mengkomunikasikan dan menetapkan ekspektasi yang jelas, menciptakan dan mempromosikan lingkungan belajar yang mendukung, 
dan menyediakan sumber daya, maka hal itu akan menuntun mereka untuk meningkatkan komitmen mereka. Hasil penelitian ini menunjukkan bahwa leaders coaching berdampak positif terhadap komitmen, temuan yang sejalan dengan penelitian sebelumnya (Akhtar \& Ziaur-Rehman, 2017). Selain itu, menggunakan tim sebagai acuan untuk komitmen organisasi dan mengikuti penelitian komitmen organisasi oleh Mowday et al. (1982), penelitian ini memprediksi bahwa ada hubungan positif antara leaders coaching dan komitmen tim. Hamlin et al. (2009) menyatakan bahwa coaching adalah praktik membantu dan memandu dosen, kelompok, dan organisasi untuk mendapatkan keahlian, kinerja, dan kemampuan baru serta mendorong peningkatan, efisiensi, dan pertumbuhan pribadi mereka. Meskipun potensi pengaruh leaders coaching terhadap modal psikologis belum banyak dieksplorasi oleh peneliti sebelumnya, hasil penelitian ini telah secara empiris mengkonfirmasi dan mendukung hipotesis bahwa leaders coaching dapat meningkatkan aspek efikasi diri, harapan, optimisme, dan ketahanan dosen, yang merupakan indikator-indikator modal psikologis. Lebih lanjut, menurut teori konservasi sumber daya/ conservation of resources theory (COR) dari Hobfoll (1989), modal psikologis dapat dipandang sebagai sumber daya individu. Dosen dengan modal psikologis positif seringkali mengharapkan hal-hal baik terjadi di tempat kerja (optimisme), percaya bahwa mereka dapat melakukan pekerjaan mereka dengan baik (self-efficacy dan harapan), dan tidak terlalu rentan terhadap kemunduran (elastisitas). Hasil penelitian ini menunjukkan bahwa modal psikologis berpengaruh positif terhadap komitmen tim. Hasil studiini sejalan dengan penelitian sebelumnya (Wang et al., 2018; Yildiz, 2017) yang menunjukkan bahwa dosen dengan modal psikologis yang lebih tinggi akan menunjukkan komitmen tim yang lebih tinggi.

Penelitian sebelumnya telah menunjukkan bahwa modal psikologis memainkan peran kunci dalam meningkatkan sikap dan perilaku kerja positif dosen sebagai konsep penting dalam teori psikologi positif (Story et al., 2013). Modal psikologis juga ditemukan menjadi mediator penting dalam penelitian sebelumnya (Raza et al., 2018). Hasil penelitian ini selaras dengan hipotesis penulis sebelumnya bahwa atasan yang menunjukkan perilaku coaching yang efektif dapat meningkatkan keadaan psikologis positif dari bawahan mereka (yaitu, efikasi diri, harapan, optimisme, dan ketahanan), yang selanjutnya dapat meningkatkan komitmen tim dosen perguruan tinggi.

\section{KESIMPULAN}

Studi saat ini berkontribusi pada literatur leaders coaching yang telah ada dengan mengeksplorasi efek dari leaders coaching pada komitmen tim dosen dan dengan memeriksa efek mediasi dari modal psikologis. Hasil penelitian ini menunjukkan bahwa leaders coaching berpengaruh signifikan terhadap modal psikologis dan komitmen tim dosen, dan bahwa modal psikologis memainkan peran mediasi yang signifikan dalam hubungan antara leaders coaching dan komitmen tim. Di antara keterbatasan penelitian tentang leaders coaching di dunia pendidikan di Indonesia, hasil studi ini bisa sedikit mengisi kekosongan tersebut. Penelitian sebelumnya menunjukkan bahwa leaders coaching adalah alat intervensi manajemen yang efektif yang dirancang untuk membantu dosen meningkatkan kemampuan mereka (Peterson \& Hicks, 1996). Selama proses coaching, manajemen perguruan tinggi dapat menggunakan berbagai teknik coaching (seperti mendengarkan, mengajukan pertanyaan, dan memberikan umpan balik) untuk mengkomunikasikan harapan organisasi kepada dosen. Manajemen perguruan tinggi dan dosen bekerja sama untuk mengembangkan tujuan kinerja dan rencana implementasi untuk mencapai tujuan tersebut. Manajemen perguruan tinggi perlu terus memberikan dukungan selama proses implementasi tugas, mendorong dosen untuk mempelajari pengetahuan dan keterampilan yang terkait dengan tugas individu. Proses leaders coaching yang efektif ini sangat mungkin membangkitkan modal psikologis positif bagi dosen, sehingga meningkatkan komitmen tim dosen.

Sebagaimana sebuah studi ilmiah, tentu penelitian ini masih terdapat kekurangan dan perlu ada perbaikan di masa mendatang. Oleh karena itu secara teoritis, saran penulis adalah: Sehubungan studi saat ini hanya meneliti komitmen tim sebagai hasil kerja dari leaders coaching. Peneliti berikutnya dapat menyelidiki dampak leaders coaching pada hasil kerja penting lainnya, seperti kinerja dalam peran dan kontekstual, motivasi kerja, turnover intention, atau komitmen profesional/karier. Secara praktis, saran penulis adalah: manajemen perguruan tinggi perlu fokus pada pembentukan sistem leaders coaching yang efektif dan dapat 
menerima feed-back yang cepat atas setiap proses coaching oleh tim manajemen. Kecepatan respon ini menjadi penting di era informasi yang mengutamakan speed dan akurasi pada setiap jenis pelayanan, sehingga pada gilirannya kinerja perguruan tinggi mampu tumbuh dan berkembang secara terus-menerus dan berkesinambungan.

\section{REFERENSI}

Agistiawati, E., Asbari, M., Basuki, S., Yuwono, T., \& Chidir, G. (2020). Exploring the Impact of Knowledge Sharing and Organizational Culture on Teacher Innovation Capability. International Journal of Science and Management Studies (IJSMS), 3(3), 62-77. http://www.ijsmsjournal.org/volume3-issue3.html

Akhtar, S., \& Zia-ur-Rehman, M. (2017). Impact of managerial coaching behavior on job performance: analyzing the role of organization commitment and role clarity. Journal of Managerial Sciences, 11(3), 298-318.

Arshadi, N. (2011). The relationships of perceived organizational support (POS) with organizational commitment, in-role performance, and turnover intention: Mediating role of felt obligation. Procedia-Social and Behavioral Sciences, 30, 1103-1108.

Asbari, M. (2019). Pengaruh kepemimpinan transformasional dan iklim organisasi terhadap kinerja dosen. JOCE IP, 13(2), 172-186. http://jurnal.ipem.ac.id/index.php/joce-ip/article/view/187

Asbari, M., \& Novitasari, D. (2021). Pengaruh Aktivitas Berbagi Pengetahuan dan Mediasi Budaya terhadap Kemampuan Inovasi Guru. JMSP (Jurnal Manajemen Dan Supervisi Pendidikan), 5(1), 324-334.

Asbari, M., Prasetya, A. B., Santoso, P. B., \& Purwanto, A. (2021). From Creativity to Innovation: The Role of Female Employees' Psychological Capital. International Journal of Social and $\begin{array}{llll}\text { Management } \quad \text { Studies } & \text { (IJOSMAS), }\end{array}$ https://ijosmas.org/index.php/ijosmas/article/view/18

Asbari, M., Purwanto, A., \& Budi, P. (2020). Pengaruh Iklim Organisasi dan Kepemimpinan Transformasional Terhadap Produktivitas Kerja Inovatif Pada Industri Manufaktur di Pati Jawa $\begin{array}{llll}\text { Tengah J Jurnal } & \text { Produktivitas, } & 7(1), & 62-69 .\end{array}$ https://doi.org/http://dx.doi.org/10.29406/jpr.v7i1.1797

Avey, J. B., Reichard, R. J., Luthans, F., \& Mhatre, K. H. (2011). Meta-analysis of the impact of positive psychological capital on employee attitudes, behaviors, and performance. Human Resource Development Quarterly, 22(2), 127-152.

Bass, B. M., \& Avolio, B. J. (1994). Improving organizational effectiveness through transformational leadership. sage.

Bernarto, I., Bachtiar, D., Sudibjo, N., Suryawan, I. N., Purwanto, A., \& Asbari, M. (2020). Effect of transformational leadership, perceived organizational support, job satisfaction toward life satisfaction: Evidences from indonesian teachers. International Journal of Advanced Science and Technology, 29(3), 5495-5503. http://sersc.org/journals/index.php/IJAST/article/view/6057

Bishop, J. W., \& Scott, K. D. (2000). An examination of organizational and team commitment in a selfdirected team environment. Journal of Applied Psychology, 85(3), 439.

Bowles, S., Cunningham, C. J. L., Gabriel, M., \& Picano, J. (2007). Coaching leaders in middle and executive management: Goals, performance, buy-in. Leadership \& Organization Development Journal.

Bowles, S. V, \& Picano, J. J. (2006). Dimensions of coaching related to productivity and quality of life. Consulting Psychology Journal: Practice and Research, 58(4), 232.

Bresser, F., \& Wilson, C. (2010). What is Coaching?. Excellence in Coaching: The Industry Guide. London: Kogan Page.

Chin, W. (1998). The Partial Least Squares Approach to Structural Equation Modeling (E. Modern Methods for Business Research, In: G. A. Marcoulides (ed.)). Lawrence Erlbaum Associates Publisher.

Diedrich, R. C. (1996). An iterative approach to executive coaching. Consulting Psychology Journal: Practice and Research, 48(2), 61.

Eisenberger, R., Huntington, R., Hutchison, S., \& Sowa, D. (1986). Perceived organizational support. Journal of Applied Psychology, 71(3), 500. 
Ellinger, A. D., Ellinger, A. E., \& Keller, S. B. (2003). Supervisory coaching behavior, employee satisfaction, and warehouse employee performance: A dyadic perspective in the distribution industry. Human Resource Development Quarterly, 14(4), 435-458.

Evered, R. D., \& Selman, J. C. (1989). Coaching and the art of management. Organizational Dynamics, 18(2), 16-32.

Fornell, C., \& Larcker, D. F. (1981). Evaluating Structural Equation Models with Unobservable Variables and Measurement Error. Journal of Marketing Research, 18(1), 39. https://doi.org/10.2307/3151312

Franks, I. M. (2018). Evidence-based practice and the coaching process. 8668(January). https://doi.org/10.1080/24748668.2002.11868256

Garmston, R., Linder, C., \& Whitaker, J. (1993). Reflections on cognitive coaching. Educational Leadership, 51(2).

Ghozali, I. (2014). Structural Equation Modeling, Metode Alternatif dengan Partial Least Square (PLS) (4th ed.). Badan Penerbit Universitas Diponegoro.

Grant, A. M. (2013). The efficacy of coaching. Handbook of the Psychology of Coaching and Mentoring, 15-39.

Grant, A. M., Curtayne, L., \& Burton, G. (2009). Executive coaching enhances goal attainment, resilience and workplace well-being: A randomised controlled study. The Journal of Positive Psychology, 4(5), 396-407.

Hackman, J. R., \& Wageman, R. (2005). A theory of team coaching. Academy of Management Review, 30(2), 269-287.

Hair, J. F., Black, W. C., Babin, B. J., \& Anderson, R. E. (2010). Multivariate Data Analysis (7th ed.). Pearson Prentice Hall.

Hobfoll, S. E. (1989). Conservation of resources: a new attempt at conceptualizing stress. American Psychologist, 44(3), 513.

Hunt, J. M., \& Weintraub, J. R. (2016). The coaching manager: Developing top talent in business. SAGE publications.

Hutagalung, D., Sopa, A., Asbari, M., Cahyono, Y., Maesaroh, S., \& Chidir, G. (2020). Influence of Soft Skills, Hard Skills and Organization Learning on Teachers' Performance through Innovation Capability as Mediator. Journal of Critical Reviews, 7(19), 54-66. http://www.jcreview.com/?mno=101978

Jones, R. A., Rafferty, A. E., \& Griffin, M. A. (2006). The executive coaching trend: Towards more flexible executives. Leadership \& Organization Development Journal.

Jumiran, Novitasari, D., Nugroho, Y. A., Sutardi, D., Sasono, I., \& Asbari, M. (2020). Pengaruh Dimensi Kepemimpinan Transformasional terhadap Kepuasan Kerja dan Komitmen Organisasional: Studi Kasus pada Dosen Perguruan Tinggi Swasta. EduPsyCouns: Journal of Education, Psychology and Counseling, 2(1), 600-621. https://ummaspul.ejournal.id/Edupsycouns/article/view/555

Kim, S., Egan, T. M., Kim, W., \& Kim, J. (2013). The impact of managerial coaching behavior on employee work-related reactions. Journal of Business and Psychology, 28(3), 315-330.

Kunst, E. M., van Woerkom, M., van Kollenburg, G. H., \& Poell, R. F. (2018). Stability and change in teachers' goal orientation profiles over time: Managerial coaching behavior as a predictor of profile change. Journal of Vocational Behavior, 104, 115-127. https://doi.org/10.1016/j.jvb.2017.10.003

Lestari, B., Novitasari, D., Silitonga, N., \& Asbari, M. (2020). The Effect of Recruitment and Career Development on The Spirit of Teachers ' Work Performance in MTs Nurul Huda. Journal of Industrial Engineering \& Management Research (JIEMAR), I(2), 108-121. https://doi.org/https://doi.org/10.7777/jiemar.v1i2

Longenecker, C. O., \& Neubert, M. J. (2005). The practices of effective managerial coaches. Business Horizons, 48(6), 493-500.

Luthans, F., \& Youssef-Morgan, C. M. (2017a). Psychological capital: An evidence-based positive approach. Annual Review of Organizational Psychology and Organizational Behavior, 4, 339366. 
Luthans, F., \& Youssef-Morgan, C. M. (2017b). Psychological Capital: An Evidence-Based Positive Approach. Annual Review of Organizational Psychology and Organizational Behavior, 4, 339366. https://doi.org/10.1146/annurev-orgpsych-032516-113324

Manz, C. C., \& Sims Jr, H. P. (1980). Self-management as a substitute for leadership: A social learning theory perspective. Academy of Management Review, 5(3), 361-367.

Merriman, D. E., \& Codding, R. S. (2008). The effects of coaching on mathematics homework completion and accuracy of high school students with attention-deficit/hyperactivity disorder. Journal of Behavioral Education, 17(4), 339.

Meyer, J. P., Allen, N. J., \& Topolnytsky, L. (1997). Commitment in a Changing World of Work. Canadian Psychology, 39, 84-93. https://doi.org/https://doi.org/10.1037/h0086797

Mowday, R. T., Porter, L. W., \& Steers, R. (1982). Organizational linkages: The psychology of commitment, absenteeism, and turnover. San Diego, CA: Academic Press.

Novitasari, D., Asbari, M., Wijayanti, L. M., Hyun, C. C., \& Farhan, M. (2020). The Role of Religiosity, Leadership Style, Job Satisfaction and Organizational Citizenship Behavior Mediation on Woman Teachers' Performance. Solid State Technology, 63(6), 2953-2967. http://solidstatetechnology.us/index.php/JSST/article/view/3380

Novitasari, D., Kumoro, D. F. C., Yuwono, T., \& Asbari, M. (2020). Authentic Leadership and Innovation: What is the Role of Psychological Capital? International Journal of Science and Management Studies (IJSMS), 3(5), 27-42. https://www.ijsmsjournal.org/volume3-issue5.html

Novitasari, D., Yuwono, T., Cahyono, Y., Asbari, M., \& Sajudin, M. (2020). Effect of Hard Skills, Soft Skills, Organizational Learning and Innovation Capability on Indonesian Teachers' Performance during Covid-19 Pandemic. Solid State Technology, 63(6), 2927-2952. http://www.solidstatetechnology.us/index.php/JSST/article/view/3379

Nuryanti, Y., Novitasari, D., Nugroho, Y. A., Fauji, A., Gazali, \& Asbari, M. (2020). Meningkatkan Komitmen Organisasional Dosen: Analisis Pengaruh Kepemimpinan Perguruan Tinggi dan Kepuasan Intrinsik \& Ekstrinsik Dosen. EduPsyCouns: Journal of Education, Psychology and Counseling, 2(1), 561-581. https://ummaspul.e-journal.id/Edupsycouns/article/view/551

Pearce, C. L., \& Herbik, P. A. (2004). Citizenship behavior at the team level of analysis: The effects of team leadership, team commitment, perceived team support, and team size. The Journal of Social Psychology, 144(3), 293-310.

Purwanto, A., Asbari, M., Hartuti, Setiana, Y. N., \& Fahmi, K. (2021). Effect of Psychological Capital and Authentic Leadership on Innovation Work Behavior. International Journal of Social and $\begin{array}{llll}\text { Management Studies } & \text { (IJOSMAS), }\end{array}$ https://ijosmas.org/index.php/ijosmas/article/view/4

Raza, B., Ali, M., Ahmed, S., \& Ahmad, J. (2018). Impact of managerial coaching on organizational citizenship behavior: The mediation and moderation model. International Journal of Organizational Leadership, 7, 27-46.

Schlechter, A. F., \& Strauss, J. J. (2008). Leader emotional intelligence, transformational leadership, trust and team commitment: Testing a model within a team context. SA Journal of Industrial Psychology, 34(1), 42-53.

Sekaran, U., \& Bougie, R. (2003). Research Methods For Business: A Skill Building Approach (Sixth edit). John Wiley and Sons, Inc.

Slåtten, T., Mutonyi, B. R., \& Lien, G. (2020). The impact of individual creativity, psychological capital, and leadership autonomy support on hospital employees' innovative behaviour. $B M C$ Health Services Research, 20(1096), 1-17. https://doi.org/https://doi.org/10.1186/s12913-02005954-4

Story, J. S. P., Youssef, C. M., Luthans, F., Barbuto, J. E., \& Bovaird, J. (2013). Contagion effect of global leaders' positive psychological capital on followers: Does distance and quality of relationship matter? The International Journal of Human Resource Management, 24(13), 25342553.

Sudiyono, R. N., Goestjahjanti, F. S., Asbari, M., Fayzhall, M., Yani, A., Winanti, Yuwono, T., Nurasiah, Yulia, Y., Singgih, E., \& Chidir, G. (2020). Meningkatkan Komitmen dan Kinerja Dosen : Apa Peran Manajemen Perguruan Tinggi? EduPsyCouns: Journal of Education, Psychology and Counseling, 2(1), 337-352. https://ummaspul.e-journal.id/Edupsycouns/article/view/489/283 
Suroso, Riyanto, Novitasari, D., Sasono, I., \& Asbari, M. (2021). Esensi Modal Psikologis Dosen: Rahasia Kreativitas dan Inovasi di Era Education 4.0. Edumaspul - Jurnal Pendidikan, 5(1), 437451. https://ummaspul.e-journal.id/maspuljr/article/view/1240

Sutardi, D., Novitasari, D., Asbari, M., Silitonga, N., Nugroho, Y. A., Hutagalung, D., Mustofa, Chidir, G., Basuki, S., \& Yuwono, T. (2020a). Pengaruh Work-Family Conflict, Stres Kerja dan Social Support terhadap Kepuasan Kerja: Studi Kasus pada Guru Wanita di Tangerang. EduPsyCouns: Journal of Education, Psychology and Counseling, 2(1), 482-498. https://ummaspul.ejournal.id/Edupsycouns/article/view/513

Sutardi, D., Novitasari, D., Asbari, M., Silitonga, N., Nugroho, Y. A., Hutagalung, D., Mustofa, Chidir, G., Basuki, S., \& Yuwono, T. (2020b). Pengaruh Work-Family Conflict, Stres Kerja dan Social Support terhadap Kepuasan Kerja: Studi Kasus pada Guru Wanita di Tangerang. EduPsyCouns: Journal of Education, Psychology and Counseling, 2(1), 482-498.

Whitmore, J. (2010). Coaching for Performance-Growing Human Potential and Purpose. SAGE Publications Sage India: New Delhi, India.

Ye, R. (Michelle), Wang, X. H. (Frank), Wendt, J. H., Wu, J., \& Euwema, M. C. (2016). Gender and managerial coaching across cultures: female managers are coaching more. International Journal of Human Resource Management, 27(16), 1791-1812. https://doi.org/10.1080/09585192.2015.1075570

Yildiz, E. (2017). The Effect of the Psychological Capital and Personality Characteristics of Employees on Their Organizational Commitment and Contribution to the Work: A Qualitative Research on Managers. Journal of Management and Strategy, 8(4), 34-46.

Yu, X., Li, D., Tsai, C.-H., \& Wang, C. (2019). The role of psychological capital in employee creativity. Career Development International.

Yuwono, T., Novitasari, D., Hutagalung, D., Sasono, I., Silitonga, N., \& Asbari, M. (2020). Peran Organizational Justice terhadap Komitmen Organisasional: Analisis Mediasi Kepuasan Kerja Dosen Perguruan Tinggi Swasta. EduPsyCouns: Journal of Education, Psychology and Counseling, 2(1), 582-599. https://ummaspul.e-journal.id/Edupsycouns/article/view/550 